\title{
THE TEAM CONCEPT IN COMMUNITY HEALTH CARE
}

\author{
JO M.M. GODDARD \\ (R.N., R.M., O.N.C., Health visitor and school nurse, \\ Diploma in Nursing (Public Health) Univ. London)
}

\section{OPSOMMING}

Gesondheidswerkers is bewus van die konsep en voordele van spanwerk maar in werklikheid word die beginsels daarvan selde toegepas.

Deur spanwerk word die kennis en vaardighede van elke lid saamgevoeg om die mees effektiewe oplossing vir 'n pasiënt se probleem te vind. Dit is noodsaaklik dat elke lid aanvaar word as individu wat 'n unieke bydrae kan lewer.

Die geneesheer is tradisioneel die leier van die gesondheidspan en te dikwels word die pasiënt se probleme volgens sy plan hanteer. Die verpleegkundige moet egter besef dat sy haar eie vaardighede het en moet bereid wees om die verantwoordelikheid daarvoor te aanvaar.

Vir die geslaagde oplossing van pasiënte se probleme moet duplisering en 'n gebrek aan kommunikasie en koördinasie in die span voorkom word. Weens volgehoue skakeling met die pasiënt en sy gesin is die gemeenskapsverpleegkundige in die ideale posisie om as koördineerder vir die gesondheidspan op te tree.

Met die uitbreiding van gesondheidsdienste en toenemende spesialisering kan een persoon nie alleen die komplekse gesondheidsprobleme van die pasiënte hanteer nie. Spanwerk moet 'n praktiese werklikheid word om 'n holistiese benadering tot gesondheidsorg te verseker.

\section{INTRODUCTION}

D espite widespread knowledge of the theory and merits of teamwork amongst health professionals, breakdown in or total omission of individual health care programmes is still happening with alarming regularity. This has a ripple effect, affecting not only the individual, but also the family, the community and the country as a whole - a state of affairs that cannot be allowed to continue.

A true team concept in the health field includes two equally important components:-

- firstly, there must be a group of professionals combining their individual knowledge and skills to achieve the most effective care of the client, his family and the community;

- secondly, the client, his family and the community must be involved and co-operate in their own health care.

Furthermore, a team is more than just a group of people operating in the same field from the same premises. It is not a medical supermarket where the client goes from section to section collecting doctoring here, counselling there and community nursing somewhere else. It is a means of uniting all available resources to handle a particular situation.

Generally, the term team refers to an intact and relatively permanent work group, comprised of colleagues and their immediate supervisor. In the health field, however, a more democratic and multidisciplinary team becomes necessary. Health teams may be more temporary in nature, meeting to achieve a particular objective or solving a particular problem. Because the problems of individual clients are so variable, the composition and skills of the team as well as the team leadership must be variable in order to deal with these problems effectively.

The relationship between members of a team is that of equal with equal. The principle involved is the acceptance that each team member has a democratic right to express his ideas and to persuade other members that his idea is right. It is accepting the right of others to differ in opinion from our own, without having hard feelings against them, that makes for the successful working of a democratic society.

A one-man dominated committee is not conducive to a good team approach. Ideally, each member should be appreciated for the special contribution he can make, and recognized as a valuable member of the team.

In the health field it is particularly important to accept each member as an individual, but in practice there are difficulties. Traditionally the doctor is accepted as the leader of the team where health is concerned. This usually means that treatment is only carried out according to a plan outlined by the doctor, which often undermines the functioning of the group as a team.

Unfortunately, this tradition still operates in many areas of community health. A course of action may be determined by one person without consultation with other team members. This may not be in the best interests of the client or his family. The fact that this tradition has perpetuated is not only the fault of the doctor, since many trained nurses still refuse to accept responsibility for their own independent functions.

For health personnel to function effectively as a team, several important elements must be present

- there must be a clearly defined reason for working together;

- the team members must firmly believe that working together as a group leads to more effective decisions and actions than working in isolation; 
- members must recognise each other's areas of expertise as well as their own limitations in certain areas of professional practice;

- the team must be prepared to include non-professionals, such as the client, his family and community workers;

- the members must develop effective channels of communication, using recognised procedures, such as case conferences, written reports, records and telephonic messages, as well as informal face to face discussion. Duplication or ommission of services must be avoided at all costs. For the nurse to operate efficiently as a full member of the team, she must be familiar with the legislation and ethics which govern her practice and be prepared to maintain a high level of professional knowledge and skill. Furthermore, she must be prepared to assert herself when her own independent functions are being threatened.

\section{THE TEAM APPROACH IN COM- MUNITY HEALTH}

The team approach in community health, as envisaged above, is not an easily organised meeting of personnel. It requires a conscious effort on the part of those involved. This is due to the physical distance between agencies and the number of different agencies involved, as well as the temporary nature of some of the health problems encountered. However, if the principles of teamwork are not adhered to, the following case study serves as an example of what frequently happens.

$\mathrm{Mr} \mathrm{S}$, an amputee, and his family. were referred to a family welfare agency at about the same time as they were referred to the Cripple Care Association by the community nurse working in the area. He had been employed after his amputation but the job he had been doing was not suited to his disablement and the artificial limb needed adjusting.

The approach of the social worker of the Cripple Care Association was to assist $\mathrm{Mr} \mathrm{S}$ in having his artificial limb re-adjusted and to make sure that he was able to use it to the best of his ability. This involved discussion with an orthopaedic technician, the physiotherapist and the occupational therapist to ascertain whether he could use the limb properly and master a different occupation, and finally consultation with employers to place him in a suitable position.

Whilst the above was being done, the family welfare agency was completely unaware of these plans and efforts and also unaware of the capabilities of an amputee and what modern therapeutic techniques could achieve. They applied for a disability grant for the man and a maintenance grant for the family. By the time the Cripple Care social worker realised the position, the client had lost any desire to work and preferred the idea of the family welfare agency - to live on State assistance.

This story points out several defects:- an overlapping of services with conflicting advice;

- a lack of communication and co-ordination between the two welfare agencies and the community nurse;

- a detrimental course of action taken by the family welfare agency because of their lack of specialised knowledge;
- inadequate assessment by medical officers who recommended a disability grant on the basis of inability to work without consulting other professional disciplines.

The lack of team effort and proper management resulted in a relatively young man losing his motivation to work and he and his family became a long-term financial burden to the State.

Diagram 1 illustrates the possible composition of a multidisciplinary team designed to assist $\mathrm{Mr} \mathrm{S}$. There is twoway communication, discussion and planning between team members and the client's welfare is their central concern. Each team member is responsible for, and decides upon, the type of care he or she will offer.

\section{DIAGRAM 1. THE POSSIBLE COMPOSITION OF A MULTIDISCIPLI- NARY TEAM DESIGNED TO ASSIST MR S.}

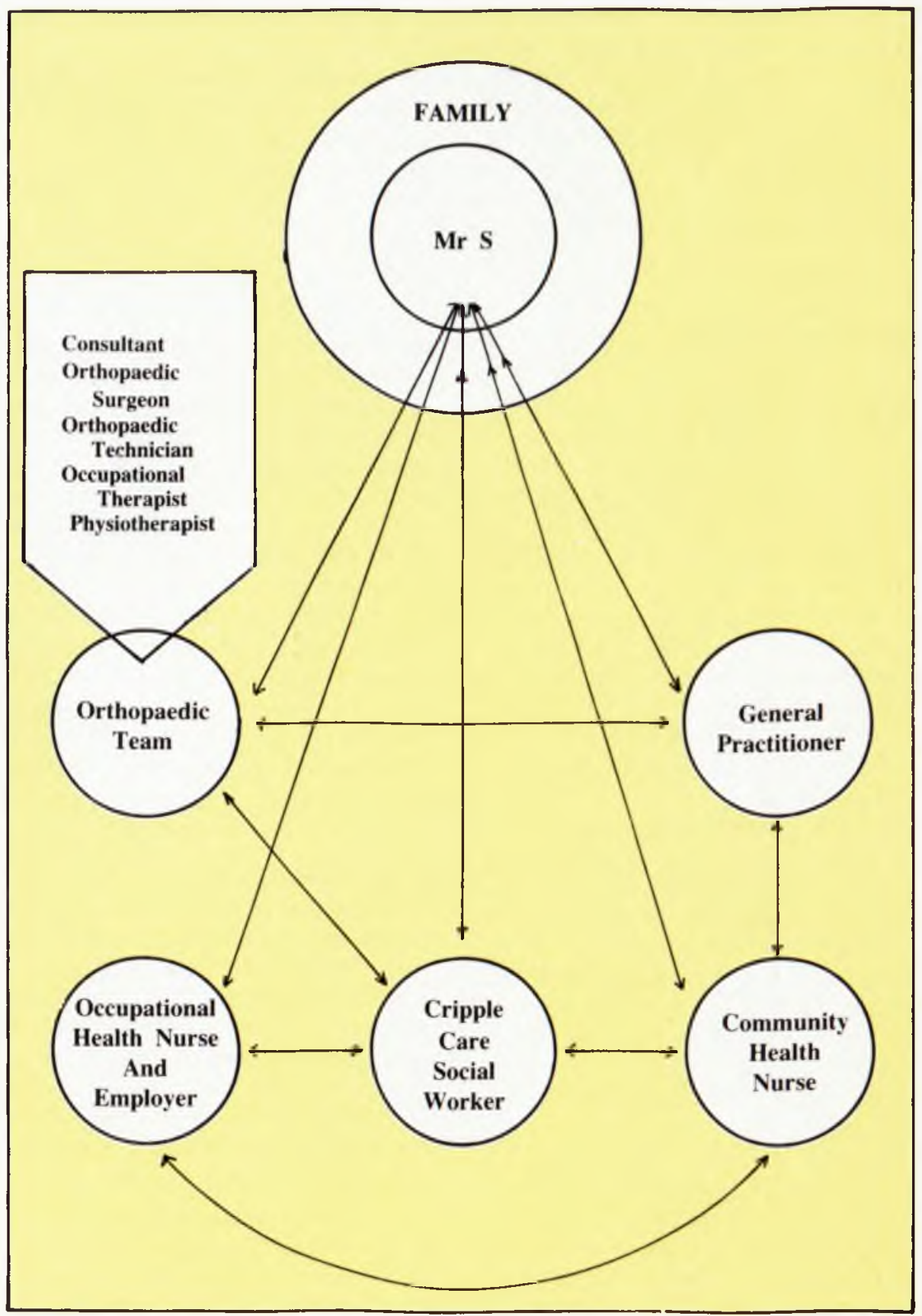




\section{THE ROLE OF THE COMMUNITY NURSE IN THE HEALTH TEAM}

The role of the community nurse in the health team is unique since, although she may not be the leader of the team at any given time, she never absolves her general responsibilities towards her clients. The community nurse can provide the other specialist workers with the background information necessary for planning the most effective care programme. She is in an ideal position to act as co-ordinator between team members, which includes the family. She is also frequently the person who identifies the problem, motivates the client to accept help and then initiates team action.

Furthermore, by virtue of her ready access to the home, the community nurse is able to provide team members with feedback regarding the client's progress.

By continued surveillance of the client and his family once therapy is completed, she is able to anticipate and possibly eliminate any predisposing factors which may lead to a recurrence of the problem. In the event of breakdown, she is in a position to reconstruct the team.

As a result of her training and job description, the community nurse is admirably equipped to be the natural centre of resources. She needs to work co-operatively with nurses in other disciplines, doctors, social workers, paramedical workers, psychologists, psychiatrists, teachers and ministers of religion as well as persons employed in the various welfare organisations and other members of the community.

With ever-increasing expansion and specialisation within health services and the complexity of clients' health problems it is clear that one person alone cannot manage the majority of health problems in isolation. For this reason the concept of the health care team must become a practical reality, aimed at a holistic approach to the client's needs.

Nothing that has been said in this article is new, but to what extent are we going to allow the phrase health care tearn to remain a mere platitude?

\section{REFERENCES}

1. Allan, S. A true team concept. Nursing Mirror. Vol 144 No 9. 3 March 1977

2. Reilly, A.J.; Jones, J.E. Team building - handbook for group facilitators. University Associate Publishers. New York. 1974 